\title{
Research and Survey on College English Teaching and humanistic Education
}

\author{
Dan $\mathrm{Li}^{1}$ and Weina Ouyang ${ }^{1, *}$ \\ ( 1 Foreign Language Education Institute, Beihua University of Jilin 132000, China) \\ Bettylidan@qq.com, 694839505@qq.com
}

\begin{abstract}
Keywords: Humanistic Education; Learning Models; human qualities; college English teaching
\end{abstract}
\begin{abstract}
According to College English Teaching Guide's saying that College English Teaching should be instrumental as well as humanistic equally, this paper is about to carry out the theoretical analysis and experiment teaching on the basis of survey on college students about the current situation of humanistic cultivation in college, and comes up with the flexibility of integration of humanistic education in college English curriculum. It's proved to be useful and meaningful for talents cultivation in college education in the new era.
\end{abstract}

\section{Introduction}

Education Department emphasized in Some advices on how to strengthen college students' cultural and qualities education that strengthening college students' humanism is a new education concept and idea[1], and it is an important part of cultivating high-quality talents by going through the whole college education. But the current situation is not satisfying for "exam-oriented education" and other reasons. College English Curriculum Teaching Requirement obviously points out that college teaching target is to cultivate students' comprehensive ability of English to meet the requirement of our country's development and international communication. So the new era's emphasis is to push forward the quality education, especially humanistic education, which can exert the individual's potential, advocate ideal personality, enlighten life meaning and improve cultural literacy. It is necessary for the society to improve talents qualities and is meaningful for the individual and the whole society.

\section{Theoretical Basis}

Humanism springs from free and rational thinking of human being's morality, intelligence and literature and arts. While science is focused on how to do something, humanism is focused on how to be a good man. However the man with only one side couldn't be all good, and in fact, to be either a good man with doing something or do something in the way of being a man is a propitiate. Only combination of scientific and humanistic spirit could establish a true personality with the development in an all-around way.

The Western education has been insisting on the primary purpose is to cultivate humanistic talents. [2] It is no doubt that any language in the world should not only a symbol system or a communication tool, but a meaning and value system of national awareness, explanation of the world. So a language has the nature nationality and humanism [3]. Domestic researches and surveys is not very optimistic and in fact, the lacking of humanistic education in English teaching is at issue and noticed by many Chinese scholars, because of the effects of exam-oriented education, it hasn't been carried out with a consistent directions and enough force. Wang Shouren mentioned specifically in Survey on current teaching in Chinese universities and College English teaching reform and development that we should bring humanistic education into teaching for it is responsible for college students' humanistic quality as one of humanistic disciplines [4] and the balance of language and culture in English teaching. Du Shizhong also stresses on English teaching as a indispensible part of humanistic disciplines should focus on the elements linguistic, literature and culture. Language is the carrier of culture, at the same time, culture is the content of language, 
and the two should be integrated in one speaker who is qualified with the humanism. [5] Besides, some other scholars discuss the importance of arrangement of general English course in college teaching, and some are committed to the models and means of integrating humanistic education into English teaching.

\section{Survey humanistic Education in College English Teaching}

The survey in the paper mainly uses Wen Qiu and Dai Weidong's survey method on the basis of learning beliefs research questionnaire for references[6], aiming to our college students' English learning and humanistic education situation, and it mainly contains students' learning objectives, autonomous learning training, cross-cultural capacity, the advices and suggestions about humanistic education and so on. For the accuracy and truth of the survey, the anonymous questionnaire is designed to be done in two district of our university, for two grades, more than ten majors, totally more than 300 students. As statistic result, the survey questionnaires given out totals 388, the number collected back is 380 , and final valid questionnaire are 375 . The final result of the survey is as follows;

On College English Learning Objectives. The questions in the survey are designed to be open in order to get the true ideas and opinions of students[7]. So many various answers are classified with their natures and meanings into different categories according to the key words. The figure below is the analysis and conclusion of the items which are chosen by more $10 \%$ students(accounting for the whole grade)

Table1. On College English Learning Objectives

\begin{tabular}{|c|c|c|c|c|c|}
\hline \multicolumn{3}{|c|}{ Grade 2015} & \multicolumn{3}{|c|}{ Grade2016 } \\
\hline Number & Key words in answers & $\begin{array}{l}(\%) \text { of } \\
\text { the grade }\end{array}$ & Number & Key words in answers & $\begin{array}{l}\text { of the } \\
\text { grade }\end{array}$ \\
\hline 1 & $\begin{array}{l}\text { Pass the exam and get the } \\
\text { degree }\end{array}$ & 62.5 & 1 & $\begin{array}{l}\text { Adjust to the society and meet } \\
\text { the challenges }\end{array}$ & 50.4 \\
\hline 2 & $\begin{array}{l}\text { Adjust to the society and } \\
\text { meet the challenges }\end{array}$ & 39.8 & 2 & $\begin{array}{l}\text { Pass the exam and get the } \\
\text { degree }\end{array}$ & 41.2 \\
\hline 3 & $\begin{array}{l}\text { Improve English } \\
\text { communication ability }\end{array}$ & 23.5 & 3 & $\begin{array}{l}\text { Improve } \\
\text { communication ability }\end{array}$ & 33.5 \\
\hline 4 & $\begin{array}{l}\text { Enhance the quality and } \\
\text { self-perfection }\end{array}$ & 19 & 4 & $\begin{array}{l}\text { Enhance the quality and } \\
\text { self-perfection }\end{array}$ & 26.3 \\
\hline 5 & $\begin{array}{l}\text { Improve English and extend } \\
\text { horizon }\end{array}$ & 19 & 5 & $\begin{array}{l}\text { Improve English and extend } \\
\text { horizon }\end{array}$ & 13.6 \\
\hline 6 & Prepare for jobs in the future & 17.5 & 6 & Prepare for jobs in the future & 12.8 \\
\hline 7 & $\begin{array}{l}\text { Know about the background } \\
\text { of Western culture }\end{array}$ & 13.5 & 7 & $\begin{array}{l}\text { Know about the background of } \\
\text { Western culture }\end{array}$ & 10.7 \\
\hline
\end{tabular}

It can be seen that $62.5 \%$ of the students at the grade 2016 take the examinations as the primary purpose of college English learning. "Adaptation to social development and meet the challenge" is ranked second in $39.8 \%$. Grade 2015 on the contrary, its primary purpose is to "adapt to social development, meet the challenge" for the test and curricula came in second. (For example, the Internet, watching English films, listening to English songs, reading English goods and even the convenience of computer courses and other courses, and so on, but these choices is all in very low proportion and can be omitted. .

On the one hand, the survey reflects the utilitarian nature of students for learning and the influence of various degree tests on four or six examinations has a great influence on students' learning orientation, especially for sophomore students. On the other hand, as the future increase in personal core competitiveness of the weight is also particularly important. At the same time, students also pay great attention to its humanities to bring their own overall quality improvement. In English learning, the first focus on training and strengthening the ability to communicate, followed by improving the level of English, and finally understand the background of Western cultural 
knowledge. Students should learn that background of Western cultural knowledge is not only conducive to improving the level of English knowledge, strengthen the pragmatic ability, but also to a large extent improve the overall quality in order to meet the future needs of the community of talent.

\section{On humanistic education in college English teaching.}

In order to understand the real thoughts and opinions of students for humanistic quality education, this survey is also designed as an open topic. the chart is now summarized as follows:

Table 2. On humanistic education in college English teaching

\begin{tabular}{|c|c|c|c|c|c|}
\hline \multicolumn{3}{|c|}{ Grade 2015} & \multicolumn{3}{|c|}{ Grade2016 } \\
\hline Number & Key words in answers & $\begin{array}{l}(\%) \text { of } \\
\text { the grade }\end{array}$ & Number & Key words in answers & $\begin{array}{l}(\%) \text { of } \\
\text { the grade }\end{array}$ \\
\hline 1 & $\begin{array}{l}\text { Don't know too much about } \\
\text { it }\end{array}$ & 41.5 & 1 & $\begin{array}{l}\text { Don't know too much about } \\
\text { it }\end{array}$ & 50.4 \\
\hline 2 & $\begin{array}{lr}\text { Excite interest, } & \text { active } \\
\text { atmosphere, } & \text { and } \\
\text { individualized } & \end{array}$ & 28.6 & 2 & $\begin{array}{l}\text { Excite interest, active } \\
\text { atmosphere, } \\
\text { individualized }\end{array}$ & 27.8 \\
\hline 3 & $\begin{array}{l}\text { improve the level of cross - } \\
\text { cultural communication }\end{array}$ & 23.5 & 3 & $\begin{array}{l}\text { improve the level of cross - } \\
\text { cultural communication }\end{array}$ & 20.5 \\
\hline 4 & $\begin{array}{l}\text { Introduction to Western } \\
\text { cultural knowledge }\end{array}$ & 10.2 & 4 & $\begin{array}{l}\text { Introduction to Western } \\
\text { cultural knowledge }\end{array}$ & 20.3 \\
\hline 5 & Only agree (no comments) & 10.2 & 5 & Only agree (no comments) & 13.6 \\
\hline 6 & $\begin{array}{l}\text { Distinguish between Chinese } \\
\text { and Western values and } \\
\text { speculative ability }\end{array}$ & 9.1 & 6 & $\begin{array}{l}\text { Distinguish between Chinese } \\
\text { and Western values and } \\
\text { speculative ability }\end{array}$ & 10.1 \\
\hline 7 & $\begin{array}{l}\text { Organize various English } \\
\text { extracurricular activities and } \\
\text { lectures }\end{array}$ & 8.0 & 7 & $\begin{array}{l}\text { Organize various English } \\
\text { extracurricular activities and } \\
\text { lectures }\end{array}$ & 10.1 \\
\hline 8 & $\begin{array}{l}\text { Change the examination } \\
\text { mode }\end{array}$ & 7.6 & 9 & $\begin{array}{l}\text { Change the examination } \\
\text { mode }\end{array}$ & 4.9 \\
\hline 9 & $\begin{array}{l}\text { intense English knowledge } \\
\text { teaching }\end{array}$ & 7. 5 & 10 & $\begin{array}{l}\text { intense English knowledge } \\
\text { teaching }\end{array}$ & 3.9 \\
\hline
\end{tabular}

From the above figure it can be seen, Grade 2015 and 2016 students' answers and their rankings are very similar, "do not know not understand the humanities education" ranked first, the percentage of the grade were $41.5 \%$ and $50.4 \%$, indicating that students Lack of adequate understanding and understanding of humanistic education. Among them, students in Grade 2015, after a year of college life, had the better understanding of the humanities education than students in Grade2016. This fully shows that colleges and universities need to strengthen the propaganda work of humanities education, and in practice through the interdisciplinary and infiltration of the course so that students really benefit from in practice through the interdisciplinary and infiltration of the course, so that students have been developed in several aspects in the knowledge, ability and quality. Furthermore, the concept of humanistic education enjoys popular support and it can promote the development of humanities education in colleges and universities.

\section{Strategies of Humanistic Education in College English Teaching}

Aiming to the survey results and analysis of student's opinions and suggestions and sum up the teaching practice used in the new humanistic quality education, the integration of humanities education and foreign language teaching integration, in practice some points need to be paid attention.

Reform Traditional Teaching model and Pay attention to General Education. The establishment of a wide range of classroom teaching objectives means English teachers in college English classroom teaching practice humanistic quality education. To explore the theme, learn to use, cultivate the practice and the spirit of innovation. A variety of teaching models can stimulate students' interest in learning; encourage students to learn initiative, teachers and students greatly 
enhanced interaction. we put the emphasis on general English teaching, aimed at achieving its teaching objectives in the comprehensive cultural literacy requirements, in order to critically view the Western culture and its core values, rich English-related elective courses, which maybe helpful for the terminology of English in English and vocational-related English, on the other hand, it provide students who are interested in English with more knowledge of learning resources[8].

Chang the Guiding Ideology of English Teaching and Promote the Overall Quality Education. Teachers ought to study in depth "College English syllabus" and its specific indicators, besides, pay attention to practical teaching work in the daily teaching of. The skills of training is only a means of thinking, while English learning the ultimate goal is to communicate in English and access to relevant knowledge and information. By that teachers can consciously focus on the cultivation of students' language skills in teaching practice, adhere to classroom teaching students as the center, education and teaching "Learning as the center", gradually promote the overall quality of students using English teaching. Clarify the guiding ideology of English skills education for the overall quality of education is very necessary for the overall teaching.

Enrich College English Teaching Modes and Cultivate Students' Personalized Development. In addition to classroom teaching, to create a cultural environment of the humanities campus, as well as create a good humanistic education environment to strengthen humanistic quality education is a very effective way. College English teaching should be out of the narrow circle of examination-oriented education, break through the shackles of teaching materials, follow the syllabus on the basis of reasonable integration of teaching content, expand the rich teaching methods. The integration of humanistic quality education and English teaching, with flexible teaching methods, can develop students' personalized development, and the use of a variety of multimedia resources, such as network and radio media are college English teaching can be fully developed and the use of teaching resources.

Enhance the Teaching of Humanistic Quality of English Teachers and Improve Teachers' Quality. Teachers, as the conductor of knowledge and spiritual civilization, are responsible for students to guide the correct outlook on life and values of the important work. English learning is not only a language learning, more importantly, a culture of learning, English teachers not only bear the task of cultivating an international vision of talent, furthermore, they should be the guide of the human and the model, as a cultural transmission, Teachers should give subtly and daily influence on the cultivation of students' quality, at same time, they should greatly improve the self-quality of humanities and teaching ability.

\section{Conclusion:}

The purpose of this paper is to explore how to improve the integration of humanistic quality education, humanistic quality education and English teaching in college English teaching, which has not been paid enough attention or even lack of quality teaching content, methods, as a supplement and recommendations for it the research is to break the traditional framework of traditional foreign language teaching. The whole society from top to bottom must be aware of the importance of personnel training, colleges and universities should shoulder the responsibility to cultivate the humanities quality of college students, so the humanities quality education into college English is to strengthen the humanities quality education one of the important methods, Only by effectively promoting English education and humanistic quality education go hand in hand, can contemporary college students move towards a new level in English knowledge and humanistic quality level. In short, college English teaching should make due contributions to .cultivating a talents with humanistic spirit, world-visions and correct value-orientation.

\section{Acknowledgements}

Beihua University Youth Education Research Project "The Research and Practice of College English Teaching humanistic education”, Project No. XJQN2016009 


\section{References}

[1]National Medium and Long Term Education Reform and Development Plan (2010-2020): China Higher Education, 2010, (Z3).

[2] Y.Q.Du, Humanistic quality education in college English teaching: Journal of Jiangsu Institute of Education (Social Science Edition), 2009, (5).

[3] X.P. Yao, Humanistic research and language research: Foreign Language Teaching and Research Press, 1995: 54-55.

[4] S.R.Wang, China's college English teaching status quo and college English teaching reform and development direction. China Foreign Language, 2011, 08 (5): 4-11

[5] S.Z.Du, The concept of humanities education: Education Theory and Practice. 1999 (9): 2-7

[6] W.P.Dai, Linguistics Theory Language Teaching: World Book Publishing Guangdong Co., Ltd. 2014.7

[7] X.Y.Hu, an Investigation on the Implementation of Humanistic Education in College English Teaching: Northwest Normal University 2003.6

[8] G.Y.Qian, Defended for non-utilitarian language theory and language theory three Classification: Foreign Language and Foreign Language Teaching, 2000, (10): 46.

Li Dan, female, born in 1980, lecturer in Public Foreign Language Education School of Beihua University, is mainly engaged in translation, linguistics studies.

Ouyang Weina, female, born in 1980, lecturer in Public Foreign Language Education School of Beihua University, is mainly engaged in English literature, linguistics studies. 